\title{
Prevalence of Plasmid Borne Ampc Gene in Multi- DrugResistant Freshwater and Soil Bacteria
}

\author{
Elza John ${ }^{1 *}$ Neethu P Shaju ${ }^{1}$ and Anu Yamuna Joseph ${ }^{2}$ \\ ${ }^{l}$ Department of Microbiology, Mar Athanasius College, Kothamangalam \\ ${ }^{2}$ Department of Biotechnology, Mar Athanasius College, Kothamangalam
}

\begin{abstract}
Ampicillin resistant E.coli, Klebsiella, Salmonella, Proteus, Bacillus, Chromobacterium, Vibrioand Pseudomonas species were isolated from water and soil samples from Kothamangalam area. All of the isolates were multidrug resistant showing resistance against 3 to 9 of the antibiotics tested.Vancomycin resistancewas most common with beta lactam resistance. Klebsiella was the most abundant isolate showing maximum resistance. The presence of ampC in plasmid was determined by PCR amplification with ampC specific primers. It was concluded that all the isolates possessed plasmid mediated ampicillin resistance.
\end{abstract}

Key Words:Multi-drug resistance, Ampicillin,Klebsiella,ampC gene, plasmid.

\section{Introduction}

Amp C $\beta$-lactamases are cephalosporinases encoded on the chromosomes of many of the Enterobacteriaceae and a few other organisms, where they mediate resistance to cephalothin, cefazolin, cefoxitin, most penicillins, and $\beta$-lactamase inhibitor- $\beta$-lactam combinations. ${ }^{[1]}$. The emission of bacteria into the aquatic environment also favours genetic exchange with previously non-resistant populations, thereby increasing the dispersion of this resistant capacity in the bacteria of the environment. ${ }^{[2]}$.The natural mortality of pathogenic bacteria is very high in extraenteral environments, their great abundance ${ }^{[3]}$ and the environmental conditions may be keeping these populations viable for some time. ${ }^{[4]}$.In the last two decades R-plasmid borne multiple resistant bacteria have been emerging as the cause of hospital borne infections and the gram negative bacteria have surpassed the gram positive pathogens in these infections. ${ }^{[5,6]}$

\section{Collection of sample}

\section{Materials And Methods}

Water and soil samples were collected in sterile container under aseptic condition. Air was sampled by open plate technique .Samples collected were Sample 1: Water sample from Kuroorthodu near Baselious Hospital, Sample 2: Water sample from Kuroorthodu 5km upstream from Baselioushospital ,Sample 3: Water sample from a well, Sample 4: Soil sample near Kuroorthodu River ,Sample 5: Soil sample away from water source ,Sample 6: Air environment of Kothamangalam.

Selection of ampicillin resistant strains

Samples were serially diluted upto $10^{7}$ dilution and spread plated on to LB agar medium with ampicillin solution. Incubated the plates at $37^{\circ} \mathrm{C}$ for 24 hours. Growth was observed after incubation. The numbers of colonies were counted.

\section{Identification of bacterial isolates}

The selected isolates were identified using Gram's staining ${ }^{[7]}$, Hanging drop method ${ }^{[8]}$ and biochemical tests ${ }^{[9]}$. Biochemical tests used were sugar fermentation test, oxidation fermentation test, mannitol motility test, indole production test, methyl red test, vogesproskauer test, citrate utilization test, urease test, nitrate reduction test,triple sugar iron agar test, coagulase test, oxidase and catalase test.

\section{Antibiotic sensitivity testing ${ }^{[10]}$}

Using a sterile wire loop colonies were picked and emulsified in peptone water and incubated.Muller Hinton agar plates were prepared.A sterile cotton swab was dipped into the bacterial suspension and was rubbed gently over the plates in several directions to obtain different planes, by rotating the plates and antibiotic discs were placed. Antibiotic disc used were ampicillin, amikacin, amoxicillin, penicillin, ciprofloxacin, vancomycin, neomycin, tobramycin, streptomycin. The plates were incubated overnight at $37^{\circ} \mathrm{C}$. Diameter of the zone of inhibition obtained around each antibiotic disc was measured and tabulated.

\section{Plasmid isolation by alkaline lysis method ${ }^{[11]}$}

Each isolate was inoculated into $5 \mathrm{ml}$ LB broth and incubated for 16 hours in a shaking incubator at $37^{0} \mathrm{C}$. Filled a micro centrifuge tube with $1.5 \mathrm{ml}$ bacterial culture and centrifuged at $12,000 \mathrm{rpm}$ for 2 minutes. 
Decanted the supernatant.Repeated step 1 in the same tube. Spin tube in micro centrifuge for 2 minute. Poured off supernatant and drain tube on paper towel.Added $100 \mu 1$ ice-cold Solution 1 to cell pellet and resuspend cells,

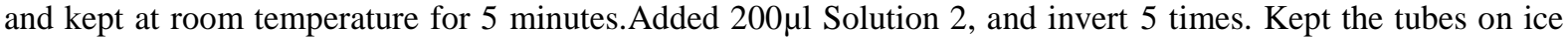
for 10 minutes.Added $150 \mu \mathrm{l}$ ice-cold Solution 3, and invert 5 times gently. Incubated tubes on ice for 10 minutes.Centrifuged tubes for 5 minutes. Transfer supernatant to fresh micro centrifuge tube. Added equal volume of tris saturated phenol mixed and centrifuged for 5 minutes at 12,000rpm.Aqueous phase was collected and added equal volume of chloroform: isoamyl alcohol.Aqueous phase was collected and added 0.6 volume of chilled isopropanol, kept on precipitation for 5 minutes.Centrifuged tubes for 20 minutes.Poured off supernatant without dumping out the pellet. Drain tube on paper towel.Added $1 \mathrm{ml}$ of ice-cold $70 \%$ ethanol.Centrifuged at 12,000rpm for 10 minutes.Poured off supernatant and drain tube. Air dried the pellet and dissolved in TE buffer.

\section{Agarose gel electrophoresis of plasmid DNA}

The isolated plasmid DNA was determined and analysed on $2 \%$ agarose gel $.5 \mu$ l of isolated plasmid DNA and $1 \mu 1$ of $6 x$ gel loading dye was mixed And loaded in to the well. Electrophoresis was done at $4 \mathrm{~V} / \mathrm{cm}$ and was started by switching on the power pack to 50 volt and then to 100volt.after the dye migrated to a sufficient distance, the gel was taken out and visualized under UV Tran - illuminator.

\section{Polymerase chain reaction}

PCR was carried out in a total of $20 \mu 1$ reaction mixture containing $1 \mu 1$ each of ampC F and ampC R, $200 \mu \mathrm{M}$ each of dNTPs, distilled water,10x buffer,50 $\mu \mathrm{g}$ DNA sample and 1 unit of taqpolymerase.The cycling condition consisted of an initial denaturation of 2 minutes at $95^{\circ} \mathrm{C}$ for 30 seconds. $58^{\circ} \mathrm{C}$ for 30 seconds and $72^{0} \mathrm{C}$ for 30 seconds. A final extension was given at $72^{\circ} \mathrm{C}$ for 10 minutes. The amplification was carried out in eppendorf master cycler personal with heated lid.

\section{Visulization of PCR products}

PCR products were subjected to agarose gel electrophoresis. Aliquots of $5 \mu 1$ of PCR products and and $1 \mu \mathrm{l}$ of 6x gel loading dye was mixed well and allowed to run in $2 \%$ agarose gel at 100v.A 100bp DNA ladder was loaded to estimate the size of the PCR product. The gel was taken out and visualized under UV transilluminator.

\section{Transformation of E.coliJM107 using plasmid DNA Preparation of competent cells}

Inoculate bacterial strain E.coli JM107 into $3 \mathrm{ml} \mathrm{LB}$ broth and incubated in a rotory shaker at $37^{\circ} \mathrm{C} 16$ hours at $220 \mathrm{rpm} .120 \mu \mathrm{l}$ of the above culture was added to $12 \mathrm{ml}$ freshly prepared LB broth and incubated at $37^{\circ} \mathrm{C}$ for 150 minutes at $220 \mathrm{rpm}$. The turbid cultures were subjected to centrifugation at $4000 \mathrm{rpm}$ for 10 minutes at $4^{\circ} \mathrm{C}$. Pellet was taken and $12 \mathrm{ml}$ chilled $5 \mathrm{mM}$ calcium chloride was added by keeping the tubes in ice. Incubated the mixture for 20 minutes in ice. It was then centrifuged to collect pellet for 5 minutes at $4000 \mathrm{rpm}$ at $4^{0} \mathrm{Cto}$ the collected pellet added $1.2 \mathrm{ml}$ of chilled calcium chloride and $180 \mu \mathrm{l}$ of glycerol was added for further storage.

\section{Transformation of plasmidDNAinto competent cells}

$150 \mu \mathrm{l}$ from the above mixture was incubated along with $1 \mu \mathrm{l}$ of plasmid .It was then subjected to heat shock at $42 \mathrm{c}$ for 1 minute and then kept on ice to provide cold shock. Both DNA and cells were incubated for 1 hour in a rotary shaker at $370 \mathrm{c}$. After 1 hour incubation $150 \mu \mathrm{l}$ of the above mixture was spread plated on 8to LB agar plates with appropriate amounts of Ampicillin. The inoculated plates are incubated at $370 \mathrm{c}$ for 16 hours for the detection of transformed colonies

\section{Detection of transformation}

The detection was based on the production of colonies on the LB agar plates containing antibiotic Ampicillin .Non transformed cells fails to produce colonies since they are Ampicillin sensitive.

\section{Confirmation of transformation}

The transformation was once again confirmed by isolation of plasmid DNA from formed colonies on LB agar plates. The colony morphology was analyzed. Transformation was done using chilled calcium chloride solution by incubating E.coliJM107 strains with plasmid DNA. Transformation was done to confirm the plasmid mediated inheritance of antibiotic resistance. 
Selection of ampicillin resistant isolates

\section{Results}

The numbers of colonies in the water samples ( 1 to 3 ) were found to be $50 \times 10^{4}, 76 \times 10^{5,} 52 \times 10^{5}$ and in soil samples ( $4 \& 5$ ) were $33 \times 10^{3}, 132 \times 10^{5}$ respectively. The air samples showed no growth in any of the LB ampicillin plates (Table 1). Out of this 33 ampicillin resistant strains were selected for the study.

Table 1: Isolation of ampicillin resistant bacteria

\begin{tabular}{|l|l|l|l|l|}
\hline Sample & $\begin{array}{l}\text { Number of colonies on LB with } \\
\text { ampicillin }\end{array}$ & $\begin{array}{l}\text { Dilution } \\
\text { factor }\end{array}$ & $\begin{array}{l}\text { Volume of sample } \\
\text { plated }\end{array}$ & CFUs \\
\hline 1 & 50 & $10^{3}$ & 0.1 & $50 \times 10^{4}$ \\
\hline 2 & 76 & $10^{4}$ & 0.1 & $76 \times 10^{5}$ \\
\hline 3 & 52 & $10^{4}$ & 0.1 & $52 \times 10^{5}$ \\
\hline 4 & 33 & $10^{2}$ & 0.1 & $33 \times 10^{3} \mathrm{CFU} / \mathrm{g}$ \\
\hline 5 & 132 & $10^{4}$ & 0.1 & $132 \times 10^{5}$ \\
\hline 6 & 0 & 0 & 0 & 0 \\
\hline
\end{tabular}

\section{Identification of bacterial isolates}

Isolates were identified as E.coli (EC1-EC4), Klebsiellasp (KL1-KL18), Salmonella sp(SAL1-2), Proteus sp(PR1),Bacillus sp (BA1-2), Chromobacteriumsp(CH1-4), Vibrio sp (VB1) and Pseudomonas sp(PS1). Results of tests are given inTable $2 \mathrm{a}$ and $2 \mathrm{~b}$.

Table 2a: Gram staining \& Biochemical tests for identification of isolates

\begin{tabular}{|c|c|c|c|c|c|c|c|c|c|c|c|c|c|c|c|}
\hline \multirow[b]{2}{*}{$\begin{array}{l}0 \\
0 \\
0 \\
0 \\
0 \\
0 \\
0 \\
0\end{array}$} & \multirow[b]{2}{*}{ 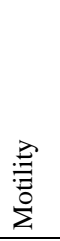 } & \multirow[b]{2}{*}{ 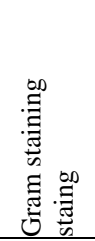 } & \multirow[b]{2}{*}{$\frac{0}{0}$} & \multirow[b]{2}{*}{ 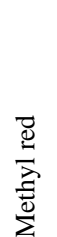 } & \multirow[b]{2}{*}{$\$$} & \multirow[b]{2}{*}{$\stackrel{\Xi}{\tilde{U}}$} & \multicolumn{3}{|c|}{ Fermentation } & \multirow[b]{2}{*}{$\frac{1}{0}$} & \multirow[b]{2}{*}{ 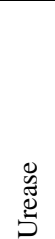 } & \multirow[b]{2}{*}{ 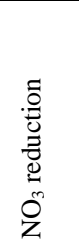 } & \multirow[b]{2}{*}{$\overline{5}$} & \multirow[b]{2}{*}{$\begin{array}{l}0 \\
\tilde{\Xi} \\
\frac{\tilde{J}}{\tilde{J}} \\
\tilde{U}\end{array}$} & \multirow[b]{2}{*}{$\begin{array}{l}0 \\
\frac{\pi}{\pi} \\
0 \\
0\end{array}$} \\
\hline & & & & & & & $\mathrm{G}$ & $\mathrm{L}$ & $\mathrm{S}$ & & & & & & \\
\hline 1 & M & NR & + & + & - & - & + & + & + & + & - & + & $\mathrm{AG} / \mathrm{A}$ & + & - \\
\hline 2 & NM & NR & - & - & + & + & + & + & + & + & + & + & $\mathrm{AG} / \mathrm{A}$ & + & - \\
\hline 3 & M & NR & - & + & - & - & + & - & - & + & - & + & $\mathrm{A} / \mathrm{AK}$ & + & - \\
\hline 4 & M & NR & + & + & - & + & + & - & + & + & + & + & AG/A & + & - \\
\hline 5 & $\mathrm{M}$ & NR & - & - & - & - & + & + & + & + & - & - & $\mathrm{AK} / \mathrm{AK}$ & - & - \\
\hline 6 & M & NR & + & + & + & - & + & + & + & + & - & + & $\mathrm{AK} / \mathrm{AK}$ & + & - \\
\hline 7 & $\mathrm{M}$ & NR & - & - & - & + & + & + & + & + & - & + & AK/AK & & \\
\hline 8 & NM & NR & - & - & + & + & + & + & + & + & + & + & $\mathrm{A} / \mathrm{AK}$ & + & - \\
\hline 9 & $\mathrm{M}$ & NR & + & + & - & - & + & + & + & + & - & + & $\mathrm{AG} / \mathrm{A}$ & + & - \\
\hline 10 & NM & NR & - & - & + & + & + & + & + & + & + & + & A/AK & + & - \\
\hline 11 & NM & NR & - & - & + & + & + & + & + & + & + & + & A/AK & + & - \\
\hline 12 & $\mathrm{M}$ & NR & + & + & - & - & + & + & + & + & - & + & $\mathrm{AG} / \mathrm{A}$ & + & - \\
\hline 13 & NM & NR & - & - & + & + & + & + & + & + & + & + & A/AK & + & - \\
\hline 14 & $\mathrm{M}$ & NR & - & - & - & - & + & + & + & + & - & - & AK/AK & - & - \\
\hline 15 & $\mathrm{M}$ & NR & - & + & - & - & + & - & - & + & - & + & $\mathrm{A} / \mathrm{AK}$ & + & - \\
\hline 16 & NM & NR & - & - & + & - & + & + & + & + & + & + & $\mathrm{A} / \mathrm{AK}$ & + & - \\
\hline 17 & NM & NR & - & - & + & + & + & + & + & + & + & + & A/AK & + & - \\
\hline 18 & $\mathrm{M}$ & NR & - & - & - & + & + & + & + & + & - & - & AK/AK & - & - \\
\hline 19 & $\mathrm{M}$ & NR & - & - & - & + & + & + & + & + & - & - & AK/AK & - & - \\
\hline 20 & NM & NR & - & - & + & - & + & + & + & + & + & + & $\mathrm{A} / \mathrm{AK}$ & + & - \\
\hline 21 & NM & $\mathrm{NR}$ & - & - & + & - & + & + & + & + & + & + & $\mathrm{A} / \mathrm{AK}$ & + & - \\
\hline 22 & NM & NR & - & - & + & - & + & + & + & + & + & + & $\mathrm{A} / \mathrm{AK}$ & + & - \\
\hline 23 & $\mathrm{M}$ & PR & + & - & + & + & + & + & + & - & + & + & $\mathrm{AK} / \mathrm{AK}$ & + & - \\
\hline 24 & NM & NR & - & - & + & - & + & + & + & + & + & + & A/AK & + & - \\
\hline 25 & NM & NR & - & - & + & + & + & + & + & + & + & + & $\mathrm{A} / \mathrm{AK}$ & + & - \\
\hline 26 & NM & NR & - & - & + & + & + & + & + & + & + & + & A/AK & + & - \\
\hline
\end{tabular}


Prevalence Of Plasmid Borne Ampc Gene In Multi- Drug Resistant Freshwater And Soil Bacteria

\begin{tabular}{|l|l|l|l|l|l|l|l|l|l|l|l|l|l|l|l|}
\hline 27 & $\mathrm{NM}$ & $\mathrm{NR}$ & - & - & + & - & + & + & + & + & + & + & $\mathrm{A} / \mathrm{AK}$ & + & - \\
\hline 28 & $\mathrm{M}$ & $\mathrm{NR}$ & + & + & - & + & + & + & + & + & - & + & $\mathrm{AG} / \mathrm{A}$ & + & - \\
\hline 29 & $\mathrm{NM}$ & $\mathrm{NR}$ & - & - & + & - & + & + & + & + & + & + & $\mathrm{A} / \mathrm{AK}$ & + & - \\
\hline 30 & $\mathrm{NM}$ & $\mathrm{NR}$ & - & - & + & + & + & + & + & + & + & + & $\mathrm{A} / \mathrm{AK}$ & + & - \\
\hline 31 & $\mathrm{NM}$ & $\mathrm{NR}$ & - & - & + & + & + & + & + & + & + & + & $\mathrm{A} / \mathrm{AK}$ & + & - \\
\hline 32 & $\mathrm{NM}$ & $\mathrm{NR}$ & - & - & + & + & + & + & + & + & + & + & $\mathrm{A} / \mathrm{AK}$ & + & - \\
\hline 33 & $\mathrm{M}$ & $\mathrm{PR}$ & + & - & + & + & + & + & + & - & + & + & $\mathrm{AK} / \mathrm{AK}$ & + & - \\
\hline
\end{tabular}

AG - Acid with gas: A - Acid: AK - Alkaline: OF - Oxidation fermentationG - Glucose: L - Lactose: S Sucrose: TSI - Triple sugar iron agar test:M-Motile: NM-Non motile: NR-Negative rod: PR-positive rod.

Table 2b: Isolates selected for study

\begin{tabular}{|c|c|c|}
\hline Sample number & Bacterial Isolates & Isolate code \\
\hline \multirow{7}{*}{1} & Escherichia coli & EC1 \\
\hline & Klebsiellasp. & KL1 \\
\hline & Salmonella sp. & SAL1 \\
\hline & Proteus sp. & PR1 \\
\hline & Chromobacterium sp. & CH1 \\
\hline & Vibrio sp. & VB1 \\
\hline & Pseudomonas sp. & PS1 \\
\hline \multirow{12}{*}{2} & Klebsiella sp. & KL2 \\
\hline & Escherichia coli & $\mathrm{EC} 2$ \\
\hline & Klebsiella sp. & KL3 \\
\hline & Klebsiella sp. & KL4 \\
\hline & Escherichia coli & EC3 \\
\hline & Klebsiella sp. & KL5 \\
\hline & Chromobacterium sp. & $\mathrm{CH} 2$ \\
\hline & Salmonella sp. & SAL2 \\
\hline & Klebsiella sp. & KL6 \\
\hline & Klebsiella sp. & KL7 \\
\hline & Chromobacterium sp. & $\mathrm{CH} 3$ \\
\hline & Chromobacterium sp. & $\mathrm{CH} 4$ \\
\hline \multirow{4}{*}{3} & Klebsiella sp. & KL8 \\
\hline & Klebsiella sp. & KL9 \\
\hline & Klebsiella sp. & KL10 \\
\hline & Bacillus sp. & BA1 \\
\hline \multirow{4}{*}{4} & Klebsiella sp. & KL11 \\
\hline & Klebsiella sp. & KL12 \\
\hline & Klebsiella sp. & KL13 \\
\hline & Klebsiella sp. & KL14 \\
\hline \multirow{6}{*}{5} & Escherichia coli & EC4 \\
\hline & Klebsiella sp. & KL15 \\
\hline & Klebsiella sp. & KL16 \\
\hline & Klebsiella sp. & KL17 \\
\hline & Klebsiella sp. & KL18 \\
\hline & Bacillus sp. & BA2 \\
\hline
\end{tabular}

\section{Antibiotic sensitivity test}

All the 33 isolates were shown to have antibiotic resistance against at least 2 antibiotics, among the 10 antibiotic tested. Only one isolate of Klebsiellasp (KL1) isolated from kuroorthodu river water near Baselious hospital was 
resistant to 9 antibiotics. All the isolates except two (CH2 \& KL16) were resistant to all the 3 beta lactam antibiotics. Resistance towards aminoglycosides, macrolide, glycopeptides and quinolones were variable. Only one isolate was found to be (KL1) resistant to ciprofloxacin while all others were sensitive. Results are shown in Table 3a, 3b, 3c and Figure 1 to 5.

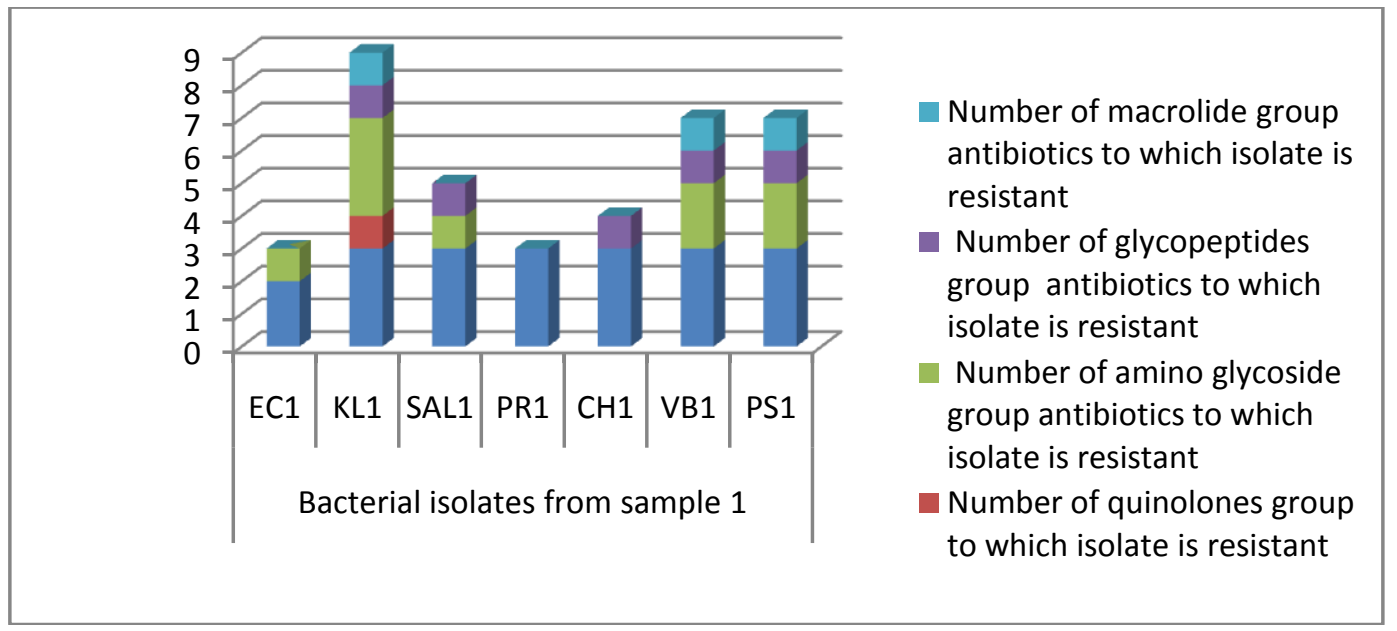

Figure 1 :Antibiotic resistance shown by isolates from sample 1

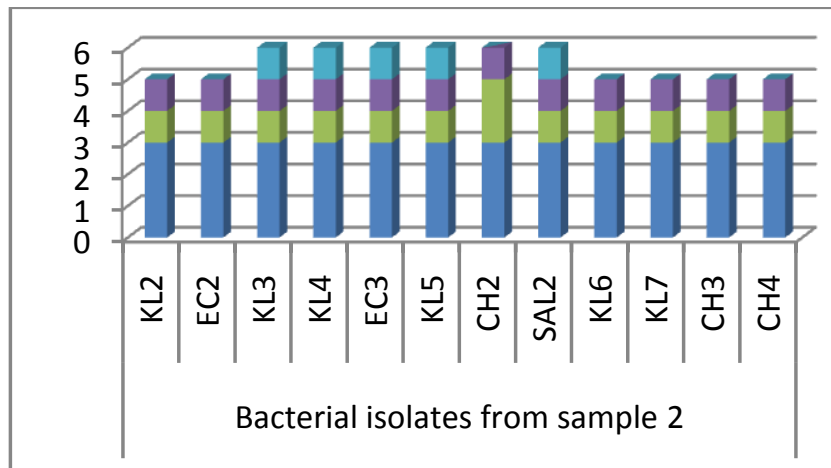

Number of macrolide group antibiotics to which isolate is

resistant

Number of

glycopeptides group antibiotics to which

isolate is resistant

Number ot amino

glycoside group antibiotics to which isolate is resistant

Figure 2 :Antibiotic resistance shown by isolates from sample 2

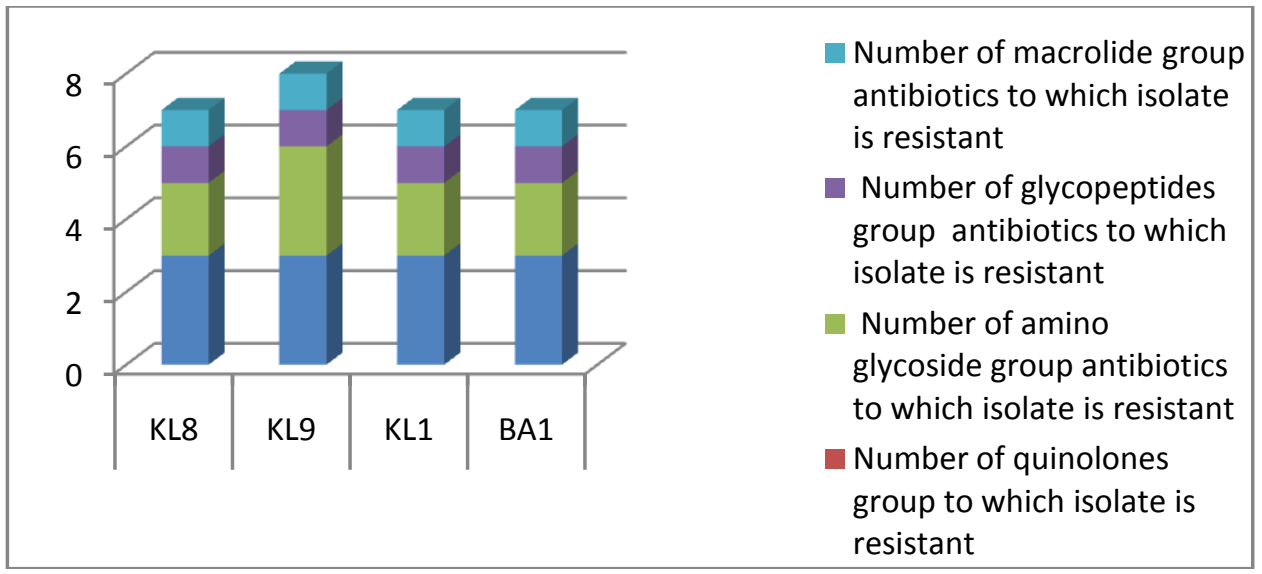

Figure 3 :Antibiotic resistance shown by isolates from sample 3 


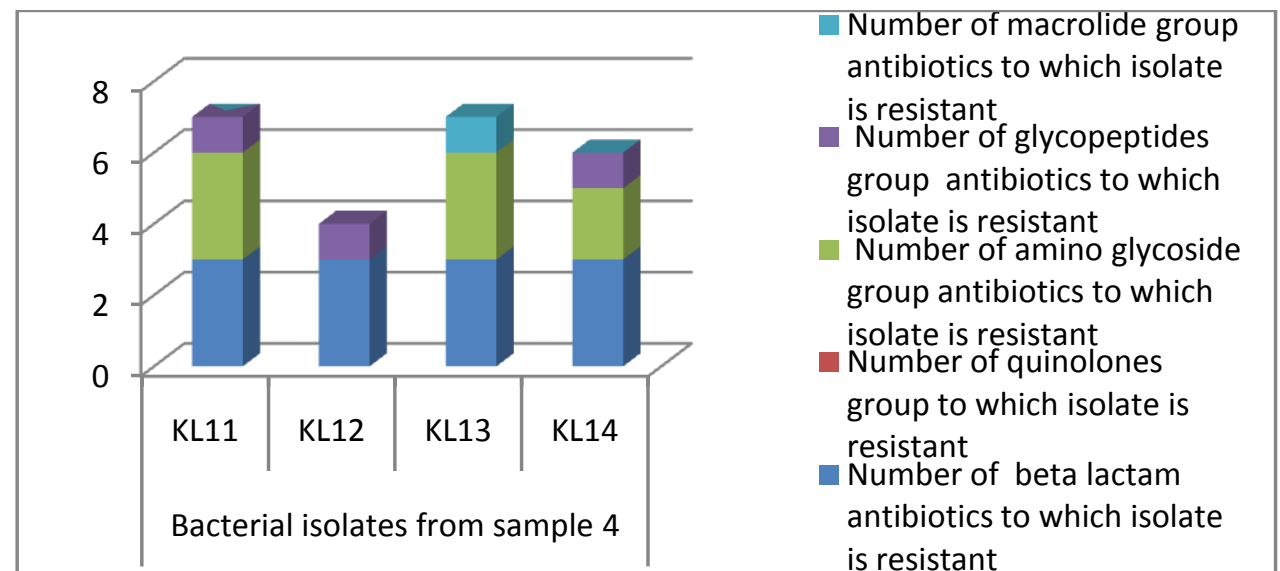

Figure 4 :Antibiotic resistance shown by isolates from sample 4

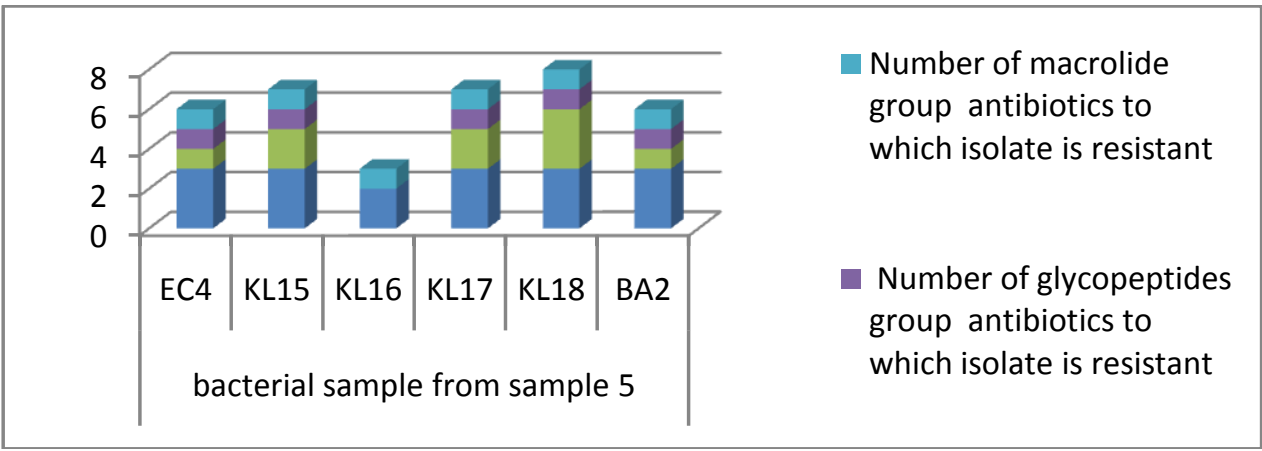

Isolation of plasmid

Figure 5 :Antibiotic resistance shown by isolates from sample 5

All 33 ampicillin resistant bacterial strains contained plasmid and the isolated plasmids were analyzed by agarose gel electrophoresis. Clear bands were obtained.

Quantification of plasmid

Plasmids isolated from the 33 ampicillin resistant strains were quantified using UV spectrophotometer. Relatively high concentrations of plasmid were obtained. OD 260 to OD 280 ratio was near the optimal value of 2 for all the samples which indicated its purity

\section{PCR amplification of ampCgene}

PCR amplification of plamid DNA samples were carried out with ampC specific primers and the resultant PCR products were electrophoresed in $2 \%$ agarose gel. Bands were seen for all isolates which indicating the positive PCR amplification .The 300bp amplicons were confirmed by the comparison with 100bp DNA ladder. This confirmed the presence of ampC gene in the plasmids isolated for all the isolates.

\section{Confirmation of plasmid mediated ampicillin resistance transfer by transformation}

All 33 plasmids were transformed into E.coliJM107 competent cell. White coloured colonies were obtained on LB ampicillin agar plates indicating successful transformation of E.coli using plasmid DNA. Clear bands were obtained by isolating plasmid from transformed colonies.

Figure.6 : PCR products of the plasmid samples

Lane1:EC1,Lane2:KL1,Lane3:SAL1.Lane4:PR1.Lane5:CHI:Lane6:VB1.Lane7:PS1, M:Marker

$$
\begin{array}{llllllll}
1 & 2 & 3 & 4 & 5 & 6 & 7 & \mathrm{M}
\end{array}
$$

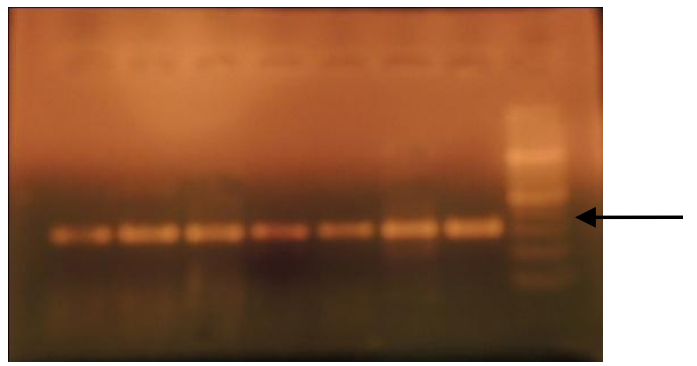




\section{Discussion}

The number of ampicillin resistant bacterial colonies isolated from Kuroorthodu river $5 \mathrm{~km}$ upstream from the Baselious hospital was found to be more than that from near hospital.Majority of the ampicillin resistant isolates from upstream wereKlebsiellaalong with ChromobacteriumandE.coli, where as in the hospital region variety of antibiotic resistant isolates were more including Klebsiella, E.coli, Pseudomonas, Vibrio, Proteus, Salmonella and Chromobacterium. In well sample the number of ampicillin resistant bacteria was less than that of river, Klebsiella was dominant. Klebsiella was predominated in the soil sample similar to water sample. Air samples failed to develop resistant bacterial isolates..

Klebsiella species from near hospital was the only isolate showed resistance to all the antibiotic including Ciprofloxacin and intermediate resistance to Neomycin.Klebsiella isolated from upstream showed resistance to 5 to 6 antibiotics. Whereas that from well showed resistance to 7 to 8 antibiotics, only one organism was resistant to streptomycin. Klebsiellafrom soil near water source showed resistance to 4 to 7 antibiotics, whereas away from water showed resistance to 2 to 8 antibiotics.

E.coli from near hospital showed resistance to only 3 antibiotics, and that from upstream showed resistance to 6 antibiotics. E.coli from soil away from water showed resistance to 6 antibiotics. Chromobacterium from near hospital was resistance to 5 antibiotics and which is upstream from hospital showed resistance to 5 to 6 antibiotics. Salmonella sp and Proteus sp from near hospital showed resistance only to 4 antibiotics. Vibrio spand Pseudomonas sp from near hospital showed resistance to 7 antibiotics .Bacillus sp isolated from soil showed resistance to 5 antibiotics whereas from well showed resistant to 7 antibiotics. The most resistant isolates of Klebsiellasp, Vibriosp, and pseudomonas sp were in river near hospital, whereas that of E.coli and Chromobacterium was from upstream water. Bacillus sp showed higher resistance in well water than soil.

The incidence of resistant strains among isolates varied significantly among the water sample, without obvious connection with the water source or the level of pollution. The average frequency of multiple resistances was not always high in the same samples in which the overall resistance was high. The species composition varied considerably in different water samples. A significant correlation was observed between the relative frequency of klebsiellasp and the incidence of ampicillin resistance in water sample. ${ }^{[12]}$

Of the five groups of antibiotics checked Quinolones group alone was able to inhibit the growth of these isolates. Only single bacteria from the near hospital developed resistance to this antibiotic group. It is an alarming situation that all the other 4 antibiotic families will be ineffective in controlling the resistant strains from the environmental samples. The isolates possessed resistance towards all the beta lactam antibiotic, 29 of the isolates were resistant to amino glycoside group and glycopeptides group antibiotics.22 isolates were resistant to macrolide group antibiotic.

This study points the fact that though the abundance of resistant isolates are more in soil, the isolates from fresh water samples showed resistance to more number of antibiotics. These fresh water sources act as more effective place for multiplication of these bacteria and hence the resistance genes like ampC genes. AmpC genes carrying plasmid was isolated from E.coli, Klebsiella, Chromobacterium, Proteus, Salmonella, Pseudomonas, Vibrio and Bacillus.

Transfer of R plasmids has been shown to occur under natural environmental conditions ${ }^{[2,13,14]}$. Since all the 33 1solates showed plasmids carrying ampC genes, we can conclude that they would be involved in transmission of resistance to other bacteria in those environments.

\section{Conclusion}

Resistant isolates were abundant in fresh water and soil samples, which was resistant to large number of antibiotics. Different aquatic compartments and soil within one municipal area were analyzed for resistant bacteria and their ampC genes.Amp resistant bacteria were widespread in the local ecosystem and Klebsiella spp. was found to be the most prevalent among the isolates.AmpCresistant genes were carried by plasmids in all the selected isolates.

Frequent use of antibiotics as medicine in treatment of humans and in food of animals results in the prevalence of antibiotics resistant bacteria. ${ }^{[15]}$ The importance of the different sources of resistance found in the environment, i.e. the presence of antibiotics in the environment and the importance of resistant bacteria result from the use of antibiotics in various fields. ${ }^{[16]}$

The antibiotics released into environment due to human activity, especially into the aquatic environment may be the reason for the development and maintenance of the ampC genes by the bacteria. Thus antibiotic resistance helps the bacteria to survive in the presence of antibiotics in nature. The presence of the resistance genes on plamids makes the exchange of genes easier between the environmental bacteria. This may explain the widespread occurrence of ampC genes in both soil \& water samples irrespective of the fact whether the source is near a hospital or not. Ciprofloxacin resistance was seen only in one isolate which was taken from water sample 
near the hospital while all other isolates from soil \& water were sensitive. This indicates a possible relation between hospital effluent and multi-drug resistance development.

In conclusion it was found that plasmid mediated antibiotic antibiotic resistance was prevalent in environment. The rapid detection of antibiotic resistance mechanism by PCR could have a significant impact on patient management in terms of appropriate antibiotic prescription and ultimately treatment outcome.The emission of antibiotics into the environment should be reduced as an important part of the risk management

\section{References}

[1]. Jacoby GA.AmpC-Lactamases. Clinical microbiology reviews. American Society for Microbiology.Lahey Clinic, Burlington, Massachusetts :2009, pp. 161-182.

[2]. Davison J. Genetic exchange between bacteria in the environment. Plasmid, $1999 ; 42: 73-91$

[3]. McFeters GA. Drinking water microbiology. New York ;Springer-Verlag: 1990, pp185-203.

[4]. Davies-Colley,Donninson RJ, Speed DJ, Ross C, Nagels JW. Inactivation of faecal indicators microorganisms in waste stabilisation ponds: Interactions of environmental factors with sunlight. Water Research, 1999; 33: 1220-1230.

[5]. Hussain RA, Wadher BJ, Hatin.Serotyping and transferability of drug resistance in clinical isolates of E. coli. Indian $\mathbf{J}$ Path Microbiol, 1995; 58:355-377.

[6]. Pillai PK,Prakash K. Current status of drug resistance and phage types of Salmonella typhiin India. Indian J Med Res, 1993;97:154158.

[7]. Cappuccino JG, Sherman N. Microbiology : A laboratory manual. $7^{\text {th }}$ ed., New Delhi; Pearson education Inc. and Dorling Kindersley: 2005, pp71-73.

[8]. Cappuccino JG, Sherman N.Microbiology : A laboratory manual. $7^{\text {th }}$ ed., New Delhi; Pearson education Inc. and Dorling Kindersley: 2005, p37-38

[9]. Cappuccino JG, Sherman N.Microbiology : A laboratory manual. $7^{\text {th }}$ ed., New Delhi; Pearson education Inc. and Dorling Kindersley: 2005, p151-193.

[10]. Navrro V, Villareal ML, Rojas G, Lozoya X. Antimicrobial activity evaluation of some plants used in medicine for the treatment of infectious diseases. J.Ethanopharmacol, 1966; 53:143-147.

[11]. Birnboim HC, Doly J. A rapid alkaline extraction procedure for screening recombinant plasmid DNA. Nucleic acids Res, 1979; 7(6): 1513-23.

[12]. Niemi M, Sibakov M,Niemela S. Antibiotic resistance among different species of fecal coliforms isolated from water samples. Appl.Environ.Microbiol, 1983;45(1):79-83.

[13]. Feuerpfeil I,López-Pila J, Schmidt R, Schneider E, Szewzyk R. Antibiotic resistant bacteria and antibiotics in the environment. Bundesgesundheitsbl.-Gesundheitsforsch.-Gesundheitsschutz, 1999; 42: 37-50.

[14]. Marcinek HR, WirthA. Muscholl-Silberhorn, and M.Gauer. Enterococcus faecalisgene transfer under natural conditions in municipal sewage water treatment plants. Appl. Environ. Microbiol,1998; 64: 626-632.

[15]. Seidler RJ, Morrow JE, Bagley ST. Klebsielleae in drinking water emanating from redwood tanks. Appl. Environ. Microbiol,1977; 33:893-900.

[16]. KümmererK. Resistance in the environment. J. Antimicrob. Chemother, 2004; 54:311- 320. 